Volume 4, Issue 1 (2020), pp. 39-44

International Journal of

Entrepreneurship and Economic Issues

ISSN: 2616-0048 Print/ ISSN: 2631-231X Online

\title{
Sri Lanka's Economic Woes amidst COVID-19 and the Way Forward
}

Nuwan Herath

General Sir John Kotelawala Defence University, Ratmalana, Sri Lanka

\begin{abstract}
Whereas the ongoing COVID-19 crisis is yet another tragic event that has added a further blow to Sri Lanka's already reeling economy, it also presents an opportunity to rethink the country's economic future. This essay argues that the way forward for Sri Lanka after the crisis is to practice traditional economics by putting in place a state-sponsored manufacturing sector, instead of relying heavily on activities like tourism and supplying migrant labor to other countries. The pandemic provides further proof that depending on such service-oriented sectors to lead the economy can have bad consequences in times of global emergencies.
\end{abstract}

Keywords: Covid-19, Manufacturing Economy, Migrant Labor, Sri Lankan Economy, Tourism

The Economist periodical recently placed Sri Lanka in one of the lowermost positions in a study of emerging markets hit by the COVID-19 crisis, ranking it in $61^{\text {st }}$ place out of 66 countries (The Economist, 2020). This position that was based on such indicators as public debt, public and private foreign debt, plus borrowing costs and reserve cover came about as yet another worrying sign that Sri Lanka was hurtling towards economic doom. 
The COVID-19 pandemic was just one more link in the chain of events that has inexorably dragged the country's tottering economy into what appears to be a hopeless situation. Of the developments that contributed to this declining strength of the economy over the recent past, several key issues stand out. One is the excessive borrowing of non-concessionary loans that led to a rapid rise in their volume from a little less than Rs.21 Billion in 2009 to Rs.52 Billion in 2017 (Shengnan, 2019). Well before the COVID-19 crisis arose, there were speculations about the decline in the 'debt sustainability' status of Sri Lanka as the 'debt service ratio' kept increasing steadily while export earnings could not maintain an equilibrium with external borrowings (Weerakoon, Kumar, \& Dime, 2019).

Secondly, the launching of massive development projects, mostly in the southern part of the island failed to deliver the promised economic benefits in return. The construction of the harbor and airport in Hambantota had increased the debt burden to such an extent that the government was obliged to lease out the same projects to the creditors, that is the Chinese state-owned corporations for 99 years (Wibisono, 2019). Also, the infamous Central Bank bond scam in 2015 damaged the credibility of the Central Bank of Sri Lanka badly. Later on, a forensic audit revealed that an estimated sum of 9.6 Billion Rupees were lost due to the fraudulent practices of the Central Bank in 2015-16, and a further sum of 9.9-10.4 Billion Rupees may have been lost during the 2005-15 period (Economynext, 2020). In addition, it was estimated that Sri Lanka had suffered more than 102 Billion Rupees of economic losses in 2018 due to the internal political crisis that was caused when the incumbent president attempted to appoint a new prime minister disregarding all constitutional provisions (Sirimanna, 2018). This was followed by the shocking Easter Sunday bombings in April 2019 that caused major losses to the tourism industry, which is one of the three main sources of foreign exchange earnings for the country (Findlay \& Dissanayake, 2019). Apart from these major setbacks that had a direct impact on the country's economic performance, other abuses such as 'political corruption', 'robbing public goods', 'accumulation of unexplained wealth' and money laundering were also taking place to the detriment of the economy (See: Abeyagoonasekera, 2020). Corruption of public officials and nepotism within the political elite were other factors that contributed to the lackluster performance of the economy by undermining growth and development. 


\section{IMPACT OF COVID-19}

The series of economic debacles that Sri Lanka had to suffer culminated with the COVID-19 crisis striking at the heart of Sri Lanka's economy. Both the manufacturing and service sectors of the economy declined by a record 24.2 and 29.8 points in the Purchasing Manager's Index (PMI), respectively (Central Bank of Sri Lanka, 2020). Yet both sectors have revived with the manufacturing sector recording a quick-paced recovery of 49.3 PMI while the service sector scored 43.1 PMI (Central Bank of Sri Lanka, 2020). Despite these indicators of recovery, two of the most vital props of the economy that collapsed were its tourism industry and remittances from migrant workers. In comparison to the previous year, the tourist arrivals declined by 70.8 percent and remittances by 13.9 percent in the month of March (PTI, 2020). At the initial stage of the outbreak of the virus, even after one Chinese tourist was found infected, the government took it lightly and was hopeful of the prospects of more tourist arrivals to Sri Lanka and so kept the ports open. An unanticipated increase in the number of patients and mounting social pressure forced the government to ban all incoming flights and ships on $22^{\text {nd }}$ March by which time 28 infected patients had been identified within the country. For an industry that the previous and present governments expected would recover in a few months after the lethal Easter Sunday attacks, the subsequent Covid-19 crisis has dealt a double whammy, and that will have severe repercussions for the national economy.

The issue of migrant labor seems more complex than the revival of tourism. According to some estimates, 17,000 migrant workers and their family members are hoping to return home but the government is facing a big challenge in repatriating them. Not only that, as there are other ramifications too, such as loss of foreign exchange earnings, re-entering them into the labor market, increase in the labor reserve in Sri Lanka due to retaining the 'would have been migrant workers', permanent repatriation or extended stay at home due to the loss of jobs or lack of valid visas etc, (Weeraratne, 2020). These unexpected challenges to an already beleaguered economy together with the increasing burden of debt will likely cause a sense of doom in time to come.

\section{POST-COVID OPPORTUNITIES AND CHALLENGES}

Probably the most important opportunity this crisis brings for developing nations like Sri Lanka is that it prompts them to rethink their economic future and strategy. After the adoption of the open economic policy in 1978, 
it persisted in this economic policy based on a voluntary acceptance of neoliberal principles even before any of its Asian neighbors. Irrespective of the arguments as to whether it was the right economic strategy at that time, Sri Lanka had the chance to capitalize on whatever opportunities the strategy might have presented if not for the fact that the civil war had started by then. According to some economists, the 1980s and 1990s were lost decades for Sri Lanka because the country failed to attract investors like the Japanese due to the political turmoil, while other countries like Malaysia were able to do so successfully (Iqbal, Hussin, \& Seman, 2015). Even after the end of the civil war, Sri Lanka's economic strategy did not deviate markedly from the earlier period. For instance, no proper initiatives were taken to enhance its international standing and stature as a service-oriented economy, though this could have been achieved by exploiting the island's geographical location in the Indian Ocean. Highly ambitious investments to make Sri Lanka a maritime, civil aviation, tourist and commercial hub only ended up with expensive infrastructure projects that increased its debt burden without yielding any fruitful returns as expected.

At this crucial juncture, Sri Lanka needs to rethink how the costly investments made on infrastructure can be salvaged and diverted to benefit the local infant industries instead of relying on services like tourism and the export of labor in the long run. Even if Sri Lanka decides to persist in a neoliberal strategy by inviting foreign investors to come, invest and generate economic prosperity with their trickle-down economic magic, that strategy will need more skilled human labor from within the country. In such a scenario, promoting migrant labor for its workers would be counterproductive as it will simply lead to a brain drain and create a shortage of labor in the island.

During the COVID-19 crisis thus far, the manufacturing sector has shown greater resilience in comparison to sectors like tourism and migrant labor. Particularly, the tea industry has continued its operations by means of online auctions, and the apparel industry, despite some initial losses due to the lockdown measures has been able to resume its functions gradually. In spite of being somewhat primitive in their own ways, these industries have been able to show some resistance in comparison to the other sectors that successive governments have relied on for taxes and foreign exchange inflows.

Due to these realities, it is high time that Sri Lanka reconsiders the positive aspects of a manufacturing economy and endeavors to build up one. It is important to recognize that all advanced capitalist countries have achieved economic success not by placing excessive reliance on services 
like tourism or migrant labor but through heavy government involvement and control over the infant industries and giving them a great deal of protection until such time as they become strong and stable (MacEwan, 2009). It is imperative that Sri Lanka have faith in its fledgling industries and utilize its infrastructure to facilitate their growth rather than rely on highly volatile sectors like tourism and migrant labor that are far more dependent on external factors that are beyond the control of the government.

\section{REFERENCES}

Abeyagoonasekera, A. (2020). Unexplained wealth and for what purpose: A Sri Lankan perspective. Journal of Financial Crime, 27(01), 24-28. https://doi.org/10.1108/JFC-12-2018-0128

Central Bank of Sri Lanka. (2020). SL Purchasing Managers' Index: PMI April 2020.

https://www.cbsl.gov.lk/sites/default/files/cbslweb_documents/press/pr /news_20200519_pmi_april_2020_e.pdf

Central Bank of Sri Lanka. (2020). SL Purchasing Managers' Index: PMI May 2020.

https://www.cbsl.gov.lk/sites/default/files/cbslweb_documents/press/pr /20200616_news_pmi_may_2020_e.pdf

Economynext. (2020, January 24). Sri Lanka may have lost Rs10.4bn from direct placement of bonds: forensic audit. Echelon Media Company. https://economynext.com/sri-lanka-may-have-lost-rs10-4bn-fromdirect-placement-of-bonds-forensic-audit-41807/

Findlay, S., \& Dissanayake, C. (2019, May 27). Terror attack weighs on Sri Lanka's economy. Financial Times. https://www.ft.com/content/dcef89f2-7529-11e9-bbad-7c18c0ea0201

Iqbal, U., Hussin, N., \& Seman, A. A. (2015). The Historical Development of Japanese Investment in Malaysia 1991-2003. Management and Administrative Sciences Review, 4(2), 275-283.

MacEwan, A. (2009). The Gospel of Free Trade. In R. Bhandari, C. Sturr, \& Dollars and Sense Collective, Real World Globalization (pp. 1-9). Boston: Economic Affairs Bureau.

PTI. (2020, June 02). Sri Lanka's economy hit by coronavirus; decline in earnings from tourism, remittances. Financial Express. 
https://www.financialexpress.com/economy/sri-lankas-economy-hitby-coronavirus-decline-in-earnings-from-tourism-remittances/1978651/

Shengnan, N. (2019). Rethinking the External Debt Issue of Sri Lanka: Causes and Implications. China International Studies, 74, 138-164.

Sirimanna, B. (2018, December 23). Treasury tightens government expenditure. Business Times. http://www.sundaytimes.lk/181223/businesstimes/treasury-tightens-government-expenditure-326080.html

The Economist. (2020, May 02). Which emerging markets are in most financial peril?. https://www.economist.com/briefing/2020/05/02/whichemerging-markets-are-in-most-financial-peril

Weerakoon, D., Kumar, U., \& Dime, R. (2019). Sri Lanka's Macroeconomic Challenges: A Tale of Two Deficits (Asian Development Bank South Asia Working Paper No.63). https://www.adb.org/publications/srilanka-macroeconomic-challenges-two-deficits

Weeraratne, B. (2020, May 18). Repatriation and replacement of lost foreign jobs: Handling labour migration during COVID-19. Lanka Business Online (LBO). https://www.lankabusinessonline.com/repatriation-andreplacement-of-lost-foreign-jobs-handling-labour-migration-duringcovid-19/

Wibisono, A. N. (2019). China's "Belt and Road Initiative" in Sri Lanka: Debt Diplomacy in Hambantota Port Investment. Jurnal Ilmu Hubungan Internasional, 02(02), 222-245.

NUWAN HERATH, is a Senior Lecturer at the Department of Social Sciences in General Sir John Kotelawala Defence University. His major research interests lie in the areas of Sociology of Religion, Peace and Conflict Resolution, and Political Economy. Email: nuwan@kdu.ac.lk 